\title{
First record of the freshwater jellyfish Craspedacusta sowerbii Lankester, 1880 in Greece suggests distinct European invasion events
}

\author{
Ioannis Karaouzas ${ }^{1} \cdot$ Stamatis Zogaris $^{1} \cdot$ Manuel Lopes-Lima $^{2} \cdot$ Elsa Froufe $^{2}$ • \\ Simone Varandas ${ }^{3} \cdot$ Amílcar Teixeira $^{4} \cdot$ Ronaldo Sousa $^{2,5}$
}

Received: 15 January 2015/ Accepted: 30 March 2015/Published online: 18 April 2015

(C) The Japanese Society of Limnology 2015

\begin{abstract}
This contribution presents the first record of the freshwater jellyfish Craspedacusta sowerbii Lankester, 1880 in Greece. The species was found in a water transfer canal adjacent to Lake Marathon, $45 \mathrm{~km}$ northeast of Athens; this is the southernmost record of this invasive alien medusa in the Balkan Peninsula and Europe. A review of recently published records shows that this species has expanded its range in Europe and the Mediterranean countries. Genetic analysis of the Greek specimen suggests that the phylogeny of $C$. sowerbii needs further evaluation since we are probably dealing with a distinct species within the genus Craspedacusta, and that the Greek population represents a distinct invasion event from that previously recorded in central Europe. However, due to a lack of
\end{abstract}

Handling Editor: Toshifumi Minamoto.

Ioannis Karaouzas

ikarz@hcmr.gr; ikarz@ath.hcmr.gr

1 Institute of Marine Biological Resources and Inland Waters, Hellenic Centre for Marine Research, 46.7 km AthensSounio Av., 19013 Anavissos, Attica, Greece

2 CIIMAR/CIMAR: Interdisciplinary Centre of Marine and Environmental Research, University of Porto, Rua dos Bragas 289, 4050-123 Porto, Portugal

3 CITAB-UTAD: Centre for Research and Technology of Agro-Environment and Biological Sciences, University of Trasos-Montes and Alto Douro, Apartado 1013, 5001-811 Vila Real, Portugal

4 CIMO-ESA-IPB: Mountain Research Centre, School of Agriculture, Polytechnic Institute of Bragança, Campus de Santa Apolónia, Apartado 1172, 5301-854 Bragança, Portugal

5 CBMA: Centre of Molecular and Environmental Biology, University of Minho, Campus de Gualtar, 4710-057 Braga, Portugal molecular information on the native and invasive ranges, further phylogenetic studies are necessary to clarify this issue.

Keywords Medusa - Invasive $\cdot$ Alien species - DNA · Phylogeny

\section{Introduction}

Craspedacusta sowerbii Lankester, 1880 is a small freshwater cnidarian (less than $25 \mathrm{~mm}$ in diameter) with a wide ecological niche, which has enabled it to colonize virtually all types of freshwater ecosystems (Boothroyd et al. 2002; Moreno-Leon and Ortega-Rubio 2009; Galarce et al. 2013). Even though deliberate introductions of this species have not been reported, this species has successfully colonized all of the continents apart from Antarctica (Dumont 1994; Jankowski 2001), and is thus considered one of the most widespread freshwater invaders.

Although initially alleged to have originated from South America, $C$. sowerbii is native to the Yangtze valley in China (Kramp 1961). It was first recorded and described from the "Victoria regia" (Victoria amazonica) tank at the Royal Botanic Society's gardens in Regent's Park, London, United Kingdom (Lankester 1880). The most plausible vector of introduction was water lily plants from Brazil (Payne 1924). The earliest reports of the occurrence of $C$. sowerbii in Europe and United States of America observed this species in artificial impoundments or botanical ponds (Bushnell and Porter 1967). In recent times, this medusa has been widely reported in artificial water bodies and, sporadically, in a variety of natural freshwater bodies such as pool habitats of streams and rivers, ponds, lakes, and reservoirs (Duggan and Eastwood 2012). Due to its high 
morphological plasticity, the taxonomy of the Craspedacusta genus has been contentious, with several conflicting species and variations being described from China and Japan (Dumont 1994; Kubota and Tanase 2006). Recently, with the aid of molecular tools, Fritz et al. (2009) revealed the existence of at least three very divergent lineages of $C$. sowerbii: the "kiatingi," the "sowerbii," and the "sinensis." In that work, all of the sequences from the specimens found in Germany and Austria belonged to the "kiatingi" lineage, indicating that the Kiating region of China is the most plausible origin of the jellyfish found in Central Europe. The predominant presence of this species in artificial water bodies suggests that it has been released due to the transportation of aquatic plants (Bushnell and Porter 1967).

This species exhibits a preference for mesotrophic to eutrophic lentic freshwater ecosystems (Jankowski et al. 2008; Moreno-Leon and Ortega-Rubio 2009; Gomes-Pereira and Dionísio 2013) and relatively warm waters (Lewis et al. 2012). It feeds on zooplankton and often develops blooms, especially during warmer periods of the year (Stefani et al. 2010). Despite the existence of many studies on the biology and distribution of this freshwater jellyfish, its impact on inland freshwater ecosystems has been inadequately studied and remains unclear (Stefani et al. 2010; Oscoz et al. 2010). Usually, C. sowerbii is discovered by chance or when looking for some other organisms of interest. Thus, the time of introduction, the establishment, and the main dispersal pathways of this species in new regions often remain unknown. In this contribution, $C$. sowerbii is reported for the first time in Greece, making this the southernmost record of the species in the Balkan Peninsula. Craspedacusta sowerbii was found in an artificial slow-flowing canal adjacent to the supplementary drinking-water reservoir of Lake Marathon. Physicochemical characteristics of this habitat are also given.

\section{Materials and methods}

\section{Examined material}

Two medusa individuals of $C$. sowerbii were collected manually from the water column of a concrete water transportation canal ( $3 \mathrm{~m}$ in width and $2 \mathrm{~m}$ in depth) adjacent to the Lake Marathon reservoir by the authors on 30 September 2014 (Figs. 1, 2). Both specimens were fixed in pure ethanol $(100 \%)$, and one was deposited in the

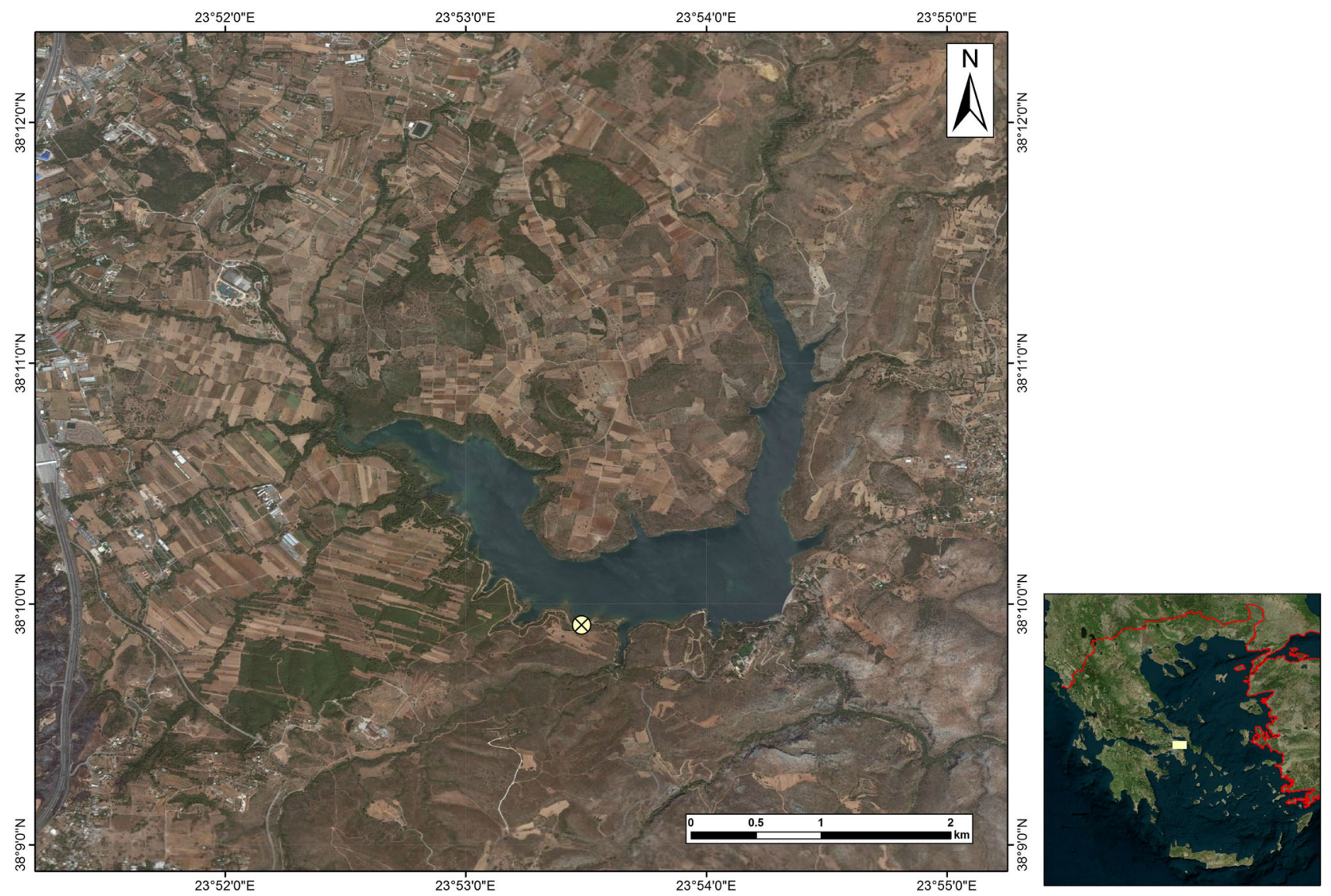

Fig. 1 Lake Marathon and the exact location where Craspedacusta sowerbii was found 


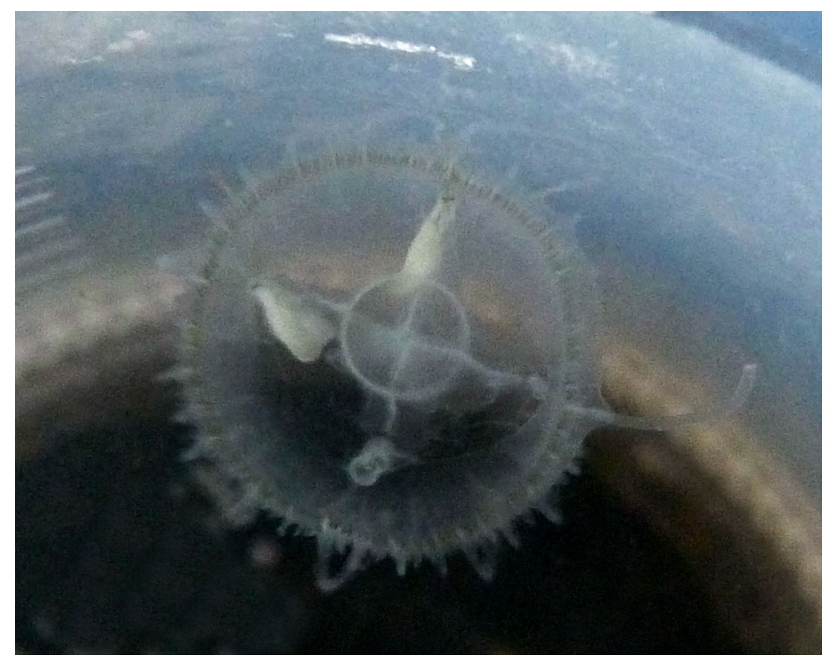

Fig. 2 Mature male Craspedacusta sowerbii medusa approximately $15 \mathrm{~mm}$ in diameter from Lake Marathon with a range of tentacle sizes and four large gonads in the center

collection of the Interdisciplinary Centre of Marine and Environmental Research, University of Porto (Portugal) while the other was deposited in the Institute of Marine Biological Resources and Inland Waters, Hellenic Centre for Marine Research (Greece). Physicochemical parameters of the canal were measured with a GPS Aquameter from Aquaread Ltd.

\section{Study area}

Lake Marathon is a drinking-water supply reservoir that was formed after the construction of Marathon Dam at the confluence of the Charadros and Varnavas streams. In order to replenish this supplementary drinking water reservoir, water is transferred to the lake by canals from two major artificial lakes (Mornos and Evinos) and the natural lake. Lake Marathon is located $45 \mathrm{~km} \mathrm{NE}$ of Athens, Attica Prefecture, at $225 \mathrm{~m}$ a.s.l. $\left(38^{\circ} 09^{\prime} \mathrm{N}\right.$ and $23^{\circ} 53^{\prime} \mathrm{E}$ ). Its catchment area is $118 \mathrm{~km}^{2}$, with an average runoff of 14,400,000 $\mathrm{m}^{3}$ year $^{-1}$ and an average rainfall of $580 \mathrm{~mm}$ year $^{-1}$. Its surface area is $2.45 \mathrm{~km}^{2}$, its maximum water depth is about $54 \mathrm{~m}$, and its maximum capacity is $41,000,000 \mathrm{~m}^{3}$ (EYDAP 2015). Since the dam was completed in 1929, its aquatic and shoreline vegetation has increased in richness. Riparian and marshland zones include Phragmites australis (Cav.) Trin. ex Steud. and Vitex agnus-castus L., which are fringed by rich terrestrial maquis and forest dominated by Pinus halepensis Miller. The lake's aquatic vertebrate community is also rich, and includes several fishes (in the genera Scardinius, Rutilus, Luciobarbus, and Pelasgus) and a rich variety of water birds (Hellenic Centre for Marine Research, unpublished observations). As it is a drinking-water storage facility,
Lake Marathon is protected, anthropogenic pressures are limited, and human access is prohibited.

\section{Genetics analysis}

Due to the taxonomic uncertainty over the genus Craspedacusta, the identity of one of the specimens was tested by genetic analysis. To achieve this, the whole genomic DNA was extracted from a small tissue sample $\left(2 \mathrm{~mm}^{3}\right)$ using the Jetquick tissue DNA Spin Kit (Genomed) according to the manufacturer's protocol. A fragment of approximately $700 \mathrm{bp}$ of the mtDNA coxl gene (CO1) was amplified by polymerase chain reaction (PCR) using universal primer modified versions, i.e., dgLCO1490 and dgHCO2198 (Meyer et al. 2005). The PCR conditions (25- $\mu \mathrm{L}$ reactions) were as follows: each reaction contained $2.5 \mu \mathrm{L}$ Invitrogen PCR buffer, $0.5 \mu \mathrm{L}$ of each primer at $10 \mathrm{mM}, 1.5 \mu \mathrm{L} 50 \mathrm{mM} \mathrm{MgCl} 2,0.5 \mu \mathrm{L} 10 \mathrm{mM} \mathrm{dNTP}$, $0.1 \mu \mathrm{L}$ Invitrogen Taq DNA polymerase, and approximately $100 \mathrm{ng}$ per $\mu \mathrm{L}$ DNA template. The cycle parameters were: initial denaturation at $94{ }^{\circ} \mathrm{C}$ for $3 \mathrm{~min}$, denaturation at $94{ }^{\circ} \mathrm{C}(30 \mathrm{~s})$, annealing at $50{ }^{\circ} \mathrm{C}(45 \mathrm{~s})$, and extension at $72{ }^{\circ} \mathrm{C}(45 \mathrm{~s})$, repeated for 38 cycles, before a final extension at $72{ }^{\circ} \mathrm{C}$ for $5 \mathrm{~min}$. Amplified DNA templates were purified and sequenced (forward and reverse) by the commercial company Macrogen Europe, using the same primers. Chromatograms were checked by eye using ChromasPro 1.7.6 (http://technelysium.com.au). The obtained sequences were aligned with all the Craspedacusta spp. CO1 sequences available on GenBank (Table 1) using ClustalW on Bioedit v.7.2.5. (Hall 1999) and adjusted manually, resulting in a final alignment of $574 \mathrm{bp}$. Four additional Limnomedusae sequences were also included in the alignment as outgroups (Table 1). The newly obtained sequence was submitted to GenBank (Table 1).

In order to confirm the species identification and to estimate evolutionary relationships, the final alignment was then analyzed using the neighbor-joining (NJ) and Bayesian inference $(\mathrm{BI})$ methods. The $\mathrm{NJ}$ analysis was performed on MEGA 6.06 (Tamura et al. 2013) with a random sequence addition (ten replicate heuristic searches), with the support for nodes estimated using the bootstrap technique with 1000 replicates. The best-fit model of nucleotide substitution evolution based on the corrected Akaike's information criterion was estimated using JModelTest 2.1.4 (Darriba et al. 2012). The BI analysis was achieved on MrBayes version 3.2.3 (Ronquist et al. 2012) under the model GTR+I. Analyses started with program-generated trees, with four incrementally default-heated Markov chains; two independent runs $1 \times 10^{6}$ generations long were sampled at intervals of 100 generations, producing a total of 10,000 trees. Burn-in was determined upon the convergence of log-likelihood and parameter estimation 
Table 1 List of Craspedacusta sowerbii $\mathrm{CO} 1$ sequences that were analyzed and their GenBank accession numbers

\begin{tabular}{lll}
\hline Locality of specimen & GenBank accession number & Study \\
\hline Marathon, Greece & KP231217 & This study \\
Sichuan province, China & KF510026 & Cai et al. \\
Hubei province, China & NC_018537 & Zou et al. (2012) \\
Hessen, Germany & FJ423613 & Fritz et al. (2009) \\
Baden-Wuerttemberg, Germany & FJ423614 & Fritz et al. (2009) \\
Baden-Wuerttemberg, Germany & FJ423615 & Fritz et al. (2009) \\
Saxony Anhalt, Germany & FJ423616 & Fritz et al. (2009) \\
Northrhine-Westphalia, Germany & FJ423617 & Fritz et al. (2009) \\
Saxony-Anhalt, Germany & FJ423618 & Fritz et al. (2009) \\
Baden-Wuerttemberg, Germany & FJ423619 & Fritz et al. (2009) \\
Rheinland-Pfalz, Germany & FJ423620 & Fritz et al. (2009) \\
\hline
\end{tabular}

${ }^{\text {a }}$ Unpublished values using Tracer 1.6 (Rambaut et al. 2014). Estimates of sequence divergence (uncorrected $p$-distances) were assessed using MEGA 6.06 (Tamura et al. 2013).

\section{Results and discussion}

The collected jellyfish (Fig. 2) presented an umbrella/bell diameter of $15 \mathrm{~mm}$ and its gonads were well defined. The gonads, which were located on the radial canals, appeared to be well developed and elongated at their distal ends, thus indicating a mature male specimen. The physicochemical characteristics of the canal adjacent to Lake Marathon during the sighting of the medusae are presented in Table 2. The population of $C$. sowerbii medusae was scattered sporadically and the density seemed to be low. At a distance of $20 \mathrm{~m}$ along the canal, only 8 individuals were visually recorded. No individuals were spotted within the reservoir, even though it was inspected at several locations. As medusa can be found as deep as $3 \mathrm{~m}$ below the water's surface (Beckett and Turanchik 1980), individuals may have been present in the reservoir.

Table 2 Values of physical and chemical parameters measured in the irrigation ditch adjacent to Lake Marathon on the date of collection (30 September 2014)

\begin{tabular}{ll}
\hline Parameter & Value \\
\hline Temperature $\left({ }^{\circ} \mathrm{C}\right)$ & 15.6 \\
Pressure (mbar) & 999 \\
$\mathrm{pH}$ & 7.91 \\
Redox potential $(\mathrm{mV})$ & 20.4 \\
Dissolved oxygen $\left(\mathrm{mg} \mathrm{L}^{-1}\right)$ & 7.87 \\
Electric conductivity $\left(\mu \mathrm{S} \mathrm{cm}^{-1} @ 20{ }^{\circ} \mathrm{C}\right)$ & 245 \\
Total dissolved solids $\left(\mathrm{mg} \mathrm{L}^{-1}\right)$ & 159 \\
Salinity $\left(\mathrm{ng} \mathrm{L} \mathrm{L}^{-1}\right)$ & 0.09 \\
\hline
\end{tabular}

The aligned CO1 sequences had a total length of $574 \mathrm{bp}$, with 207 polymorphic and 176 parsimony-informative sites. No indels and no unexpected stop codons were observed after translating all sequences to amino acids. The tree topologies resulting from the single tree recovered using the $\mathrm{NJ}$ and $\mathrm{BI}$ approaches were congruent, and results of both analyses are shown in Fig. 3. Two major mtDNA clades were retrieved with strong support: the first included the new Greek specimen sequence plus the one from Hubei province, China; the second included all the sequences from the German specimens and also the one from Sichuan province, China (Fig. 3). This pattern suggests that the phylogeny of Craspedacusta sowerbii needs further evaluation, since both clades display $15 \%$ divergence (uncorrected $p$-distance), indicating that we are probably dealing with distinct species within the genus Craspedacusta. Unfortunately, the $\mathrm{CO} 1$ sequences available in GenBank come from only two countries in Europe: Germany and now Greece. Our results show that, as the newly sequenced Greek individual does not cluster together with the German ones, there would appear to have been at least two invasion events in Europe, one in which the species invaded Germany and another in which it recently invaded Greece, which most likely also correspond to two distinct Craspedacusta spp. Further studies concerning the phylogeny of this species in the native and invaded ranges should be performed in order to clarify this issue.

In most cases of biological invasion it is very difficult to trace the vectors and pathways of introduction and the subsequent dispersion (Simberloff et al. 2013). For this particular species, dispersal may include the transfer of the cnidarians in aquaria and commercial plant nursery grounds that host water plants (Gasith et al. 2011). Dumont (1994) proposed that aerial dispersal by birds of the cnidarian's drought-resistant resting stages may lead to movement among wetlands. The Marathon area has several 
Fig. 3 Phylogenetic tree obtained by Bayesian inference and neighbor-joining analyses using mtDNA fragments (CO1). KP231217 pertains to the Lake Marathon sample. Support values are given as Bayesian posterior probabilities above nodes and as bootstrap support values below nodes. Available sequences downloaded from GenBank and the new sequence codes refer to Table 1

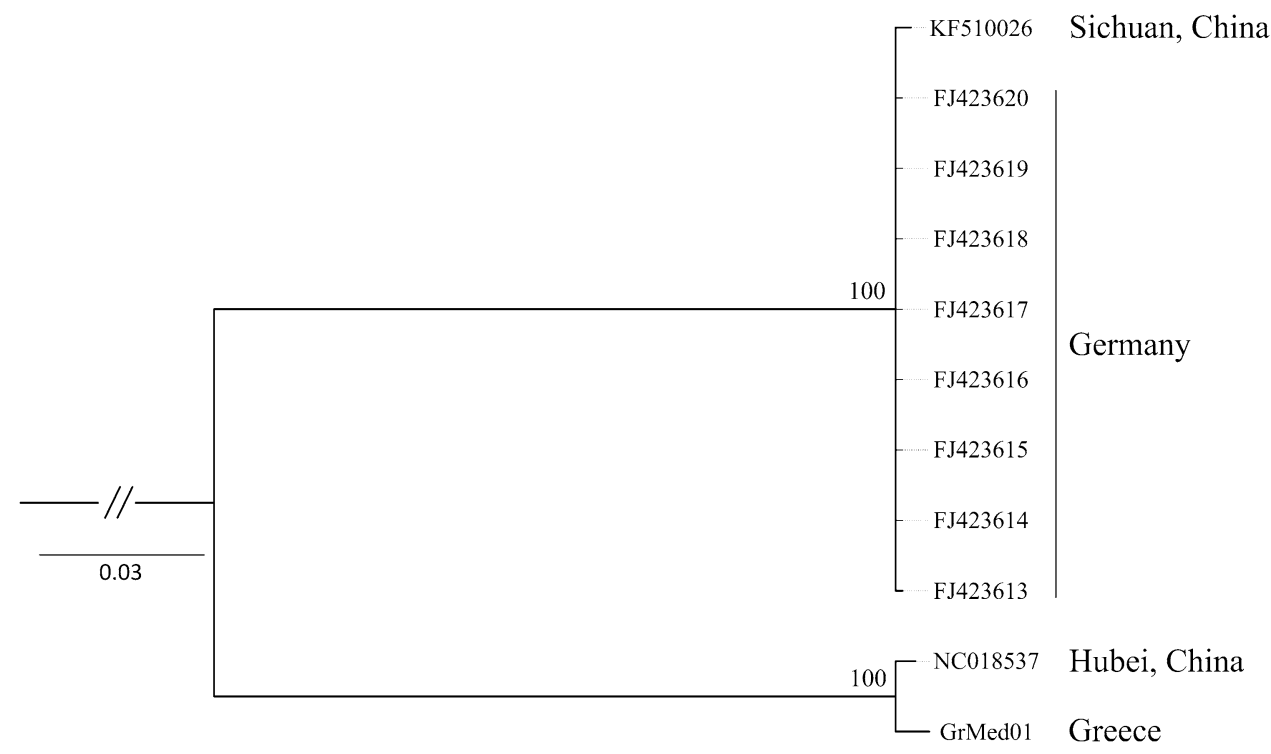

plant nursery gardens and hosts a large number of migratory water birds.

As with most hydrozoans, the life cycle of $C$. sowerbii includes both benthic polyp and free-swimming medusa stages (Lewis et al. 2012). Its successful worldwide distribution is usually attributed to several traits, such as its capacity for vegetative reproduction, its prolonged survival in new habitats with limited or no sexual reproduction (Payne 1924; Reisinger 1957), and its ability to develop a durable chitin-covered resting body phase under unfavorable conditions (Bouillon and Boero 2000), thus enhancing its survival and capacity to disperse to different freshwater habitats.

In Europe, the first records of $C$. sowerbii can be traced back to the end of the nineteenth century (from the UK, France, and Germany), whereas there has been more recent documentation of this species from many localities in Italy, Spain, Sweden, and Portugal (Ferreira 1985). In the Balkan Peninsula, the species was first recorded in 1958 from several localities in Serbia (Jakovčev-Todorović et al. 2010) and Montenegro (Milovanović and Živković 1965), while it was recorded in Croatia and Bulgaria in 1992 and 1994, respectively (Jaslovska and Stloukal 2004). The species has recently been documented in Albania (Dhora 2011) and near the Mediterranean coast of Turkey (Aysel et al. 2011) as well. This is the first record of the freshwater jellyfish $C$. sowerbii in Greece, and we speculate that it could be more common and widespread than is apparent from this incidental observation. Greece's freshwaters, even many protected lakes and sensitive reservoirs, are poorly monitored for alien species (Zenetos et al. 2009), so populations of this alien may have been overlooked until now.

In temperate regions, medusae of $C$. sowerbii have mostly been recorded during the summer period (Dumont
1994); these observations are often related to rising water temperatures and increased nutrient input (Gasith et al. 2011). Most records of polyps report observations made during the summer, thus indicating increased growth and reproduction during warm periods (De Vries 1992; PérezBote et al. 2006). Although the literature mentions the species in several types of artificial water bodies such as quarry ponds, gravel pits, reservoirs, aquaria, and even wastewater treatment facilities, records of the species within concrete-based flowing canals are limited or infrequently reported (Gasith et al. 2011). However, many reports from several regions document its occurrence in artificial freshwater habitats, especially reservoirs, such as in the Iberian Peninsula (Pérez-Bote et al. 2006; GomesPereira and Dionísio, 2013) and in Serbia (JakovčevTodorović et al. 2010). In Monte da Rocha Dam in southern Portugal, the species probably arrived via the Sado River that enters the dam (Gomes-Pereira and Dionísio 2013). Similarly, in Lake Marathon, the species may have entered from the Charadros stream or Varnavas stream, from canal inputs from the natural Lake Yliki, or from the artificial lakes Mornos and Evinos which feed Lake Marathon. This means that all of the freshwater bodies connected to the lake must be inspected for the possible occurrence of $C$. sowerbii.

Several studies have attempted to investigate the potential effects of $C$. sowerbii on freshwater ecosystems; however, their effects on local communities remain inadequately studied (Stefani et al. 2010; Oscoz et al. 2010; Gasith et al. 2011). Several studies have reported that the diet of $C$. sowerbii includes a variety of cladocerans, copepods, and rotifers (Dodson and Cooper 1983; Boothroyd et al. 2002; Moreno-Leon and Ortega-Rubio 2009). When abundant, the medusae can affect the 
population dynamics of zooplankton and significantly decrease their abundance (Jaslovska and Stloukal 2004). Dumont (1994) speculated that $C$. sowerbii medusae consume fish eggs and larvae, although-perhaps due to its small size-it is generally not considered an important predator of fish eggs or larvae. In contrast, polyps are able to consume hatched young fry, algae, nematodes, oligochaetes, crustaceans, water mites, insects, and arachnids (Bushnell and Porter 1967). Although the medusa may reduce zooplankton stocks, this reduction is not large enough to affect fish populations (Dodson and Cooper 1983). Overall, it appears that impacts on zooplankton are density dependent and can be more profound during warm temperatures when medusa populations increase. There is no information on the extent of limnological disturbance caused by $C$. sowerbii to a drinking water reservoir or its adjacent waters.

\section{Conclusions}

This is the first record of the freshwater jellyfish $C$. sowerbii in Greece. We speculate that this species may be more widespread in Greece than is apparent from this incidental observation because artificial reservoirs and wetlands are rarely surveyed for alien organisms in Greece. Additionally, genetic analysis showed that the phylogeny of $C$. sowerbii needs further evaluation, since we are probably dealing with different species within the genus Craspedacusta and the Greek population represents a distinct invasion event from that previously recorded in central Europe. Further molecular analysis of specimens from both its native and invaded regions is needed to understand the dynamics of the invasion of this genus around the world.

Alien species are important influences on ecosystem structure and functioning, and it is known that $C$. sowerbii can affect zooplankton communities. Therefore, surveys addressing the population dynamics of this species should be performed that target both the medusa and the polyp forms in the Greek freshwater ecosystem in which the species occurs. Finally, since the species appears to be restricted to a small area and still has a low abundance, this specific phase of population development is the most appropriate period to implement efficacious measures to eradicate or at least control further dispersion and reduce the impacts of this unintentional introduction.

Acknowledgments The authors wish to express their appreciation to the two anonymous reviewers and the handling editor of this work for their valuable comments which helped to improve this manuscript.

\section{References}

Aysel B, Memet V, Bulent G (2011) A new record of the freshwater jellyfish Craspeducusta sowerbii Lankester, 1880 (Hydrozoa) in Southeastern Anatolia (Turkey). Chin J Oceanol Limn 29:366-368

Beckett DC, Turanchik EJ (1980) Occurrence of the freshwater jellyfish Craspedacusta sowerbyi Lankester in the Ohio River. Ohio J Sci 80:95-96

Boothroyd IKG, Etheredge MK, Green JD (2002) Spatial distribution, size structure, and prey of Craspedacusta sowerbii in a shallow New Zealand lake. Hydrobiologia 468:23-32

Bouillon J, Boero F (2000) The hydrozoa: a new classification in the light of old knowledge. Thalassia Salentina 24:3-45

Bushnell JH, Porter WT (1967) The occurrence, habitat, and prey of Craspedacusta sowerbyi (particularly polyp stage) in Michigan. T Am Microsc Soc 86:22-27

Darriba D, Taboada GL, Doallo R, Posada D (2012) jModelTest 2: more models, new heuristics and parallel computing. Nat Methods 9:772

De Vries DR (1992) The freshwater jellyfish Craspedacusta sowerbyi: a summary of its life history, ecology, and distribution. J Fresh Ecol 7:7-16

Dhora DH (2011) Register of species of the fauna of Albania 2010. Botimet Camaj-Pipa, Shkodër

Dodson SI, Cooper SD (1983) Trophic relationships of the freshwater jellyfish Craspedacusta sowerbyi Lankester 1880. Limnol Oceanogr 28:345-351

Duggan IC, Eastwood KR (2012) Detection and distribution of Craspedacusta sowerbii: observations of medusae are not enough. Aquat Invasions 7:271-275

Dumont HJ (1994) The distribution and ecology of the fresh and brackish-water medusae of the world. Hydrobiologia 272:1-12

EYDAP (2015) Water supply resources: fact sheet on the Marathon Reservoir. https://www.eydap.gr/en/TheCompany/Water/Water Sources, last accessed 5 Jan 2015

Ferreira MT (1985) Occurrence of the freshwater medusa Craspedacusta sowerbyi Lank, 1880 (Hydrozoa: Olindiidae) in Portuguese reservoirs. Bol Soc Port Ciênc Nat 22:41-46

Fritz GB, Pfannkuchen M, Reuner A, Schill RO, Bruemmer F (2009) Craspedacusta sowerbii, Lankester 1880-population dispersal analysis using COI and ITS sequences. J Limnol 68:46-52

Galarce LC, Riquelme KV, Osman DY, Fuentes RA (2013) A new record of the non indigenous freshwater jellyfish Craspedacusta sowerbii Lankester, 1880 (Cnidaria) in Northern Patagonia (40으, Chile). Bioinvasions Rec 2:263-270

Gasith A, Gafny S, Hershkovitz Y, Goldstein H, Galil BS (2011) The invasive freshwater medusa Craspedacusta sowerbii Lankester, 1880 (Hydrozoa: Olindiidae) in Israel. Aquat Invasions 6(1):S147-S152

Gomes-Pereira JN, Dionísio G (2013) Craspedacusta sowerbii Lankester, 1880 in southern Portugal. Bioinvasions Rec 2:133-136

Hall TA (1999) Bioedit: a user friendly biological sequence alignment editor and analysis program for Windows 95/98/NT. Nucleic Acids Symp Ser 41:95-98

Jakovčev-Todorović D, Đikanović V, Skorić S, Cakić P (2010) Freshwater jellyfish Craspedacusta sowerbyi Lankester, 1880 (Hydrozoa, Olindiidae): 50 years' observations in Serbia. Arch Biol Sci 62:23-127

Jankowski T (2001) The freshwater medusae of the world-a taxonomic and systematic literature study with some remarks on other inland water jellyfish. Hydrobiologia 462:91-113

Jankowski T, Collins AG, Campbell RD (2008) Global diversity of inland water cnidarians. Hydrobiologia 595:35-40 
Jaslovska M, Stloukal E (2004) Invasion of freshwater medusa, Craspedacusta sowerbyi into Carpathian and Pannonian area. In: Stloukal E, Kaluz S (eds) Book of abstracts-Fauna Carpathica Meeting. Faunima, Bratislava, p 20

Kramp PL (1961) Synopsis of the medusae of the world. Order Limnomedusae. J Mar Biol Assoc UK 40:213-236

Kubota S, Tanase H (2006) Biological notes on mature freshwater medusae, Craspedacusta sowerbyi (Hydrozoa, Limnomedusae, Olindiidae), from south-central Wakayama Prefecture, Japan. Bull Biogeogr Soc Japan 61:75-79 (in Japanese with English abstract)

Lankester ER (1880) On a new jellyfish of the order Trachomedusae, living in freshwater. Science 1:34

Lewis C, Migita M, Hashimoto H, Collins AG (2012) On the occurrence of freshwater jellyfish in Japan 1928-2011: eightythree years of records of mamizu kurage (Limnomedusae, Olindiidae). P Biol Soc Wash 125:165-179

Meyer CP, Geller JB, Paulay G (2005) Fine scale endemism on coral reefs: archipelagic differentiation in turbinid gastropods. Evolution 59:113-125

Milovanović D, Živković A (1965) Plankton Skadarskog jezera (1957-1958). Zbornik Radova Biol Inst Beograd 8:1-36

Moreno-Leon MA, Ortega-Rubio A (2009) First record of Craspedacusta sowerbyi Lankester, 1880 (Cnidaria: Limnomedusae: Olindiidae) in Mexico (Adolfo Lopez Mateos reservoir), with notes on their feeding habits and limnological dates. Biol Invasions 11:1827-1834

Oscoz J, Tomás P, Durán C (2010) Review and new records of nonindigenous freshwater invertebrates in the Ebro River basin (Northeast Spain). Aquat Invasions 5:263-284

Payne F (1924) A study of the freshwater medusae, Craspedacusta ryderi. J Morphol 38:387-430

Pérez-Bote J, Muñoz A, Morán R, Roso R, Romero AJ (2006) First record of Craspedacusta sowerbyi Lankester, 1880 (Cnidaria:
Limnomedusae: Olindiidae) in the Proserpina Reservoir (Extremadura, SW Spain) with notes on their feeding habits. Bel J Zool 136:163-166

Rambaut A, Suchard MA, Xie D, Drummond AJ (2014) Tracer v1.6. http://beast.bio.ed.ac.uk/Tracer, last accessed 30 Nov 2014

Reisinger E (1957) Zur Entwicklungsgeschichte und Entwicklungsmechanik von Craspedacusta (Hydrozoa, Limnotrachylina) (in German). Z Morph Ökol Tiere 45:656-698

Ronquist F, Teslenko M, van der Mark P, Ayres DL, Darling A, Höhna S, Larget B, Liu L, Suchard MA, Huelsenbeck JP (2012) MrBayes 3.2: efficient Bayesian phylogenetic inference and model choice across a large model space. Syst Biol 61:539-542

Simberloff D, Martin J-L, Genovesi P, Maris V, Wardle D, Aronson J, Courchamp F, Galil B, Garcia-Berthou E, Pascal M, Pyšek P, Sousa R, Tabacchi E, Vilà M (2013) Impacts of biological invasions: what's what and the way forward. Trends Ecol Evol 28:58-66

Stefani F, Leoni B, Marieni A, Garibaldi L (2010) A new record of Craspedacusta sowerbii, Lankester 1880 (Cnidaria, Limnomedusae) in Northern Italy. J Limnol 69:189-192

Tamura K, Stecher G, Peterson D, Filipski A, Kumar S (2013) MEGA6: molecular evolutionary genetics analysis version 6.0. Mol Biol Evol 30:2725-2729

Zenetos A, Pancucci-Papadopoulou MA, Zogaris S, Papastergiadou E, Vardakas AL, Aligizaki K, Economou AN (2009) Aquatic alien species in Greece (2009): tracking sources, patterns and effects on the ecosystem. J Biol Res Thessalon 12:135-172

Zou H, Zhang J, Li W, Wu S, Wang G (2012) Mitochondrial genome of the freshwater jellyfish Craspedacusta sowerbyi and phylogenetics of Medusozoa. PLoS One 7:e51465 